\title{
Cleantech: State of the Art and Implications for Public Procurement
}

\author{
Robert Davtyan \\ Hanken School of Economics and HUML OG Institute, Finland \\ robert.davtyan@hanken.fi \\ Wojciech Piotrowicz \\ Hanken School of Economics and HUMLOG Institute, Finland \\ wojciech.piotrowicz@hanken.fi
}

\begin{abstract}
This paper explores opportunities for utilising cleantech in framing research on sustainability-oriented innovations in public procurement. Research objectives include a critical examination of whether cleantech is a distinct sector through a systematic literature review and synthesis of findings with public procurement research. The final analysis involved 31 peerreviewed academic papers along with additional publications obtained with the snowball-approach. The results suggest that cleantech could be used to analyse sustainability related research in the public procurement context. Cleantech is also helpful in enhancing research on public procurement of innovations and addressing societal benefits through local development. Findings unveil new opportunities in investigating better access of SMEs to public contracts through intermediaries, networks, and public-private partnerships. This paper is the first academic paper to analyse academic cleantech literature and link cleantech and public procurement fields. Such an approach is helpful in framing sustainability in public procurement research and stresses new ways of involving smes in public contracts.
\end{abstract}

Key Words: cleantech, innovation, public procurement, sustainability JEL Classification: $\mathrm{H} 57, \mathrm{Q} 56$

(c) BY.SA https://doi.org/10.26493/1854-6935.19.185-207

\section{Introduction}

A gradual increase in using management fads and different concepts originating from practitioners has become a natural tendency among the academic community. Some concepts have indeed carved a niche in academia, while others are under discussion as to whether they represent new valuable techniques or are just new terms that relabel existing phenomena. 'Cleantech', which did not exist as a concept before early 
20oos, emerged and gained momentum as a socio-technical sector encompassing an immense range of environmental technologies and services (Caprotti 2012). While the term is being widely used in the industry, cleantech as a concept is still overlooked by scholars, especially in comparison with other recent trends in technology and management, such as blockchain.

In the meanwhile, public procurement, originally evolving as an operational activity, has itself become an academic discipline. Defined as 'the designated legal authority to advise, plan, obtain, deliver, and evaluate government's expenditures on goods and services that are used to fulfil stated objectives, obligations, and activities in pursuant of desired policy outcomes' (Prier and McCue 2009, 329), public procurement has been used as a strategic lever towards achieving specific economic, political, and social goals, which can be traced back to the 19th century (McCrudden 2004). Scholars have acknowledged the relevance of public procurement as a tool for stimulating markets and increasing demand for innovative solutions in general (Guerzoni and Raiteri 2012; Hommen and Rolfstam 2009), and reducing environmental impact by transition to low carbon procurement (Correia et al. 2013) as well as influencing markets of green and environmentally friendly products and services (Cheng et al. 2018). Purchasing, used throughout this study synonymic to procurement, is considered the most feasible process of supply chain management to incorporate a sustainable agenda (Ashby, Leat, and HudsonSmith 2012). Notwithstanding the various benefits society can obtain by economic utilization of taxpayers' money, there are still challenges prevailing in the context of public procurement research. To date, public context and related policies add considerable complexity in assessing both economic and environmental aspects of procurement (De Giacomo et al. 2018). Despite increased academic attention to the field (Eßig and Glas 2016), the findings accumulated to date are rather dispersed (Snider and Rendon 2008; Telgen, Harland, and Knight 2007; Thai 2001; Uyarra and Flanagan 2010). However, there is an indication of shortages of green (Testa et al. 2016) and innovative (Uyarra and Flanagan 2010) public procurement literature, whereas evidence on innovative effects of public procurement is fragmented (Georghiou et al. 2014). In the light of the lack of both theoretical- and empirical-based research, more specific and systematic studies on the appearance of sustainability in public procurement research are required (Cheng et al. 2018).

Cleantech tends to be discussed on various levels. In practice, policy- 
makers recognise and employ the concept. Examples include the Finnish government's resolution on promoting cleantech solutions through public procurement and recommendations for municipalities on its adoption (Ministry of the Environment 2013), and setting up a Government Programme to become a pioneer in cleantech, and the circular- and bioeconomy (Prime Minister's office 2015). Despite the relevance of interconnecting cleantech and public procurement, such a research direction has not yet been explored widely, with only one scholarly paper (Alhola and Nissinen 2018) containing 'cleantech' and 'public procurement' as the keywords, unveiling the evidence of successful cleantech cases in innovative public procurement, and focusing on practical implications.

This paper, therefore, strives to systematise insights examining cleantech literature and research, considering the potential of cleantech and its presence in governmental agendas. An assumption is that cleantech can take the role of a tool transferring general sustainability goals into more measurable metrics, which is one of the biggest challenges in contemporary public procurement research (Cheng et al. 2018; De Giacomo et al. 2018) and framing the research on public procurement of innovations (PPI).

This paper has two main objectives. Firstly, the aim is a critical overview of whether cleantech is an independent sector, as specified by some scholars (see Caprotti 2012). For this purpose, underlining prevalent definitions, determining the boundaries of a sector, and examining interrelations with other sustainability-related terms will be done by systematic review of academic literature. Secondly, research agenda and specific directions synthesising the key features of cleantech and public procurement streams of literature will be outlined.

The paper is structured as follows. An overview of the interrelation between public procurement and innovations will initiate the paper, followed by methodology. Consequently, key findings from selected cleantech-related literature according to the main objectives will be presented. Finally, these insights will be applied to the field of public procurement in order to depict further research directions.

\section{Public Procurement, Innovations, and SMes}

This section demonstrates the interrelation between public procurement, stimulation of innovations and the specific role of small- and mediumsized enterprises (SMEs). These insights will then serve as a prerequisite for consequent mapping of the systematic literature review findings. 
The notion of positive impact public procurement on innovations is not new, as it originates in the 1970 (Edler and Georghiou 2007). The emphasis of policymakers has been put on the potential of public demand to stimulate innovation development, new technologies diffusion and commercialization (Uyarra et al. 2017). Public policy is defined as all direct and indirect state actions that have an impact on citizens (Snider and Rendon 2008), and innovative public procurement represents only one type of governmental innovative public policy instrument. Research and Development (R\&D) subsidies, along with universities and research units, are the direct governmental instruments, while public procurement and regulations are the demand-side tools (Aschhoff and Sofka 2009). $\mathrm{R} \& \mathrm{D}$ subsidies are a recognised alternative to innovative public procurement (Guerzoni and Raiteri 2012); however, from the long-term perspective, public procurement shows more efficiency in stimulating innovations than direct R\&D investments (Edler and Georghiou 2007). 'Pulling' innovations by creating demand and markets for further commercialising has proven more efficient than directly 'pushing' these technologies to markets with a lack of demand.

Taxonomic issues of innovative public procurement have been discussed widely. Uyarra and Flanagan (2010) highlight the homogeneity of academic attempts towards classification that consolidate current products and services and advances in transmission of existing services. Research streams and topics related to the synthesis of public procurement and innovation on a global scale have been further categorised by Obwegeser and Müller (2018) as Public Procurement for Innovation (P PfI), Public Procurement of Innovation (PPOI) and Innovative Public Procurement (IPP). Intensity of public demand and tendencies to procure innovative products and services (Hommen and Rolfstam 2009) also implicitly affects the innovative agenda of companies by cherishing modernisation of current products and services despite existence of public orders. Furthermore, project volume, technological ramification and legal barriers ought to be considered and analysed adequately within any specific context. However, Chicot and Matt (2018) differentiate between catalytic PPI, whereby innovation development and diffusion are enhanced, and diffusive PPI, which boosts innovations uptake without addressing supply-side disruptions. Similarly, Gee and Uyarra (2013) discuss the important role of public procurement, specifically in local contexts, and the impact of power asymmetry on system innovation orchestration, while Uyarra et al. (2017) pinpoint the thin line between regular and innovative 
public procurement, as in practice the concepts do not represent anything notably different. The reviewed research indicates cities and municipalities as platforms of public procurement capable of creating new markets. Such platforms are more attractive for piloting and experimenting new solutions. Likewise, an innovative agenda is applicable to green public procurement (GPP), in which incorporation of environmental criteria to public products and services is the cornerstone. GPP can boost innovations by setting environmental criteria for public procurement, though recent findings indicate an absence of both theoretical and empirical investigations on the topic, as well as a lack of attempts to connect it to cleantech (Cheng et al. 2018). Thus, GPP and PPI do not represent different concepts, as they complement each other.

The above-mentioned parallel is particularly relevant from the perspective of small- and medium-sized enterprises (SMES), whose higher innovative performance correlated with public sector demand (Saastamoinen, Reijonen, and Tammi 2018). The rationale for higher involvement of sMEs from an innovative perspective has been acknowledged by public procurers because of several factors. Firstly, smes are considered more innovative than their larger counterparts, especially in emerging technological fields (Frietsch, Neuhäusler, and Rothengatter 2013), and among technology-based smes and start-ups (Myoken 2010). Secondly, the flexibility and agility of smaller entities play a valuable role in innovations delivery (Karjalainen and Kemppainen 2008). Considering the interweaving nature of innovations and sustainability, addressing sustainability through local procurement is particularly successful in construction, social services and healthcare, industries that are the most comfortable for Smes (Kivistö and Virolainen 2017). Moreover, local procurement is helpful for minority- and women-owned business (Karjalainen and Kemppainen 2008; Loader 2015).

Nevertheless, there are still considerable challenges related to SMEs as public innovators, as only $29 \%$ of above-threshold contracts are secured by SMES in the EU single market (Flynn 2017). The reasons are rather systemic, as they have remained similar for over 20 years (Loader and Norton 2015) and are relevant for both the purchasing and selling sides. Public procurement entities tend to face political and institutional pressure to procure collaboratively (Meehan, Ludbrook, and Mason 2016). Despite the advantages for suppliers, such as predictable and stable income, reliability, and the opportunity to commercialise new products and services (Flynn 2017; Loader and Norton 2015), only $7 \%$ of the UK SMES 
were interested in selling to the public sector (Karjalainen and Kemppainen 2008). Moreover, $78 \%$ of small companies in the UK have never bid for nor performed public orders (Loader and Norton 2015), suggesting that the problems and barriers hindering access of SMEs to public contracts are not one-sided, but dyadic in nature.

\section{Methodology}

This paper presents a critical analysis of cleantech literature with subsequent application of the results through the lens of public procurement to outline further research agenda. The methodology is based on the systematic literature review (SLR) and content analysis.

Literature reviews are of vital importance in any scientific inquiry process, as they stand for an 'essential first step and foundation when undertaking a research project' (Baker 2000, 233), while Seuring and Gold (2012) argue that literature reviews represent the backbone of any fragment of scholarly work. Typically, the focus of the review is placed on achieving the two following goals: (1) encapsulating existing research by identifying common patterns and arguments, and (2) consequently determining the conceptual content of the area (Seuring and Müller 2008). Applying a systematic scope to the reviews underlines conducting a structured procedure of inquiring into available evidence in a transparent and reproducible manner to achieve reliable and genuine results (Rousseau, Manning, and Denyer 2008). The essential starting point of an SLR is setting the basic criteria and delineating the boundaries of a research (Denyer and Tranfield 2009). The dominant challenge of such reviews stems from the inability to read everything and, hence, the higher importance of proper boundary setting.

Therefore, it is possible to provide holistic and all-inclusive reviews only within very narrowed and emerging fields (Seuring and Müller 2008). Scopus was used to search for papers with the keywords 'cleantech' or 'clean-tech.' However, word collocations such as 'clean technologies' and 'cleaner technologies' were not included, as the main objective of the research is to comprehend the substance of 'cleantech' as a key concept. The decision is also supported by consideration of growing use of this concept by businesses in corporate responsibility matters, while 'clean technology' is almost absent in corporate sustainability communication (Frig et al. 2018). For the same reasons, journals from all disciplines were included.

The initial search resulted in 845 papers in total. The main criteria of 
TABLE 1 Papers: Descriptive Information

\begin{tabular}{lrr}
\hline Area/journal & Number of papers & Time period \\
\hline Energy and Sustainability & 16 & $2009-2018$ \\
Carbon Management & 1 & 2011 \\
Wood: Research Papers, Reports, Announcements & 1 & 2016 \\
Energy Economics & 1 & 2017 \\
\hline Energy Policy & 3 & $2009-2017$ \\
Energy Procedia & 1 & 2014 \\
Energy Research \& Social Science & 1 & 2018 \\
Environment and Planning C: Politics and Space & 1 & 2017 \\
Environmental Economics and Policy Studies & 1 & 2016 \\
Environmental Innovation and Societal Transitions & 1 & 2018 \\
Global Environmental Change & 1 & 2013 \\
International Journal of Global Warming & 1 & 2012 \\
Journal of Cleaner Production & 1 & 2011 \\
Sustainability & 1 & 2017 \\
Sustainable Cities and Society & 1 & 2014 \\
\hline Geography and General Management & 6 & $2012-2017$ \\
Economic Geography & 1 & 2014 \\
Journal of Business Economics & 1 & 2013 \\
\hline
\end{tabular}

Continued on the next page

inclusion for further review were related to document type and paper relevance. Limiting to peer-reviewed journal publications revealed $53 \mathrm{pa}$ pers, and resultant evaluation allowed excluding purely technical (such as chemistry-related) and irrelevant papers. Finally, 31 papers were selected, and utilised following a scrupulous review conducted independently by two researchers. Table 1 represents a descriptive summary of the sources of the journals selected for the review with information on journal categories and timeframes.

Relevance of papers was determined by initial screening of titles, abstracts, and keywords. The contents of the papers considered relevant were then analysed to determine the set of papers for review. Afterwards, additional papers were identified using the snowball approach by checking the references used within the selected papers. The final set of 31 papers was reviewed by the advanced content analysis method that provides a categorising technique of examining information by revealing patterns 
TA B LE 1 Continued from the previous page

\begin{tabular}{lrr}
\hline Area/journal & Number of papers & Time period \\
\hline Regional Studies & 2 & $2015-2017$ \\
Small Business Economics & 1 & 2017 \\
Transactions of the Institute of British Geographers & 1 & 2012 \\
\hline Interdisciplinary & 7 & $2008-2020$ \\
Industry and Higher Education & 1 & 2016 \\
International Review of Financial Analysis & 1 & 2016 \\
Nanotechnology Law \& Business & 1 & 2008 \\
Science and Public Policy & 1 & 2017 \\
Science of the Total Environment & 1 & 2020 \\
Technology Review & 1 & 2009 \\
The Journal of High Technology Management Research & 1 & 2010 \\
\hline Supply chain, Operations and Purchasing & 2 & $2015-2018$ \\
Industrial Marketing Management & 1 & 2015 \\
Journal of Public Procurement & 1 & 2018 \\
\hline
\end{tabular}

and directions of its elemental aspects (Seuring and Gold 2012). More specifically, selected papers were cross-checked, determining definitions of cleantech, common research directions and intersections with public procurement and policies. Moreover, the results of cross-checking appear in a measurable way (Harwood and Garry 2003), which is specifically important within a review comprising different research areas. The main modes of categorising papers and areas of focus are: Defining cleantech, Governmental involvement and policies, Cleantech firms and networks. These modes have been determined by in-depth analyses of the papers and consequent extraction of common topics of discussions.

\section{Cleantech and Governmental Involvement}

The main goal of this section is to analyse cleantech-related academic publications. Investigation starts with examining definitions in order to grasp the essence of the concept to link cleantech to the model of governmental innovative policy tools. Such an approach will allow better understanding of cleantech concept positioning from an academic perspective to the public sector needed for consequent analysis of cleantech actors and their roles in knowledge creation, taking into consideration relevance of public policies. 


\section{CLEANTECH DEFINITIONS}

The variety of papers underlines the importance of identifying the term of cleantech systematically, as it differs from other similar or overlapping sustainability-related terms, given the fact of the absence of a commonly accepted definition (Cumming, Henriques, and Sadorsky 2016; Davies 2013). To begin with, Guziana (2011), from the top-down perspective, indicates that cleantech stands apart from the concept of environmental technology, as the latter is a collective term comprising various sectors. Similarly, Hermelin and Rämö $(2017,131)$ argue that even though the overall nature of the concept is a part of a broader green economy idea, the difference stems from the point that cleantech stands for 'specific ideas of economic-environmental efficiency, green growth and market environmentalism.' Fragmented context-specific uses of the concept also take place, such as the complementary use of cleantech and greentech by means of sustainable technologies in the energy sector (Laurens et al. 2016), limiting meaning to renewable energy solely (Knuth 2018), and convergence of cleantech and nanotech in the case of greening nanotechnologies (Wexler, Murr, and Weber 2008). Nevertheless, the general interpretation of cleantech underlines comparable logic among scholars. Giudici, Guerini, and Rossi-Lamastra (2019) specifically underscore the key difference between greentech, referring to it as a small and regulatorydriven market adopting 'end-of-pipe' technological solutions, and cleantech, which is characterised by approaching fundamental environmental challenges and working on innovations to a large number of processes. A line between cleantech and bioeconomy, which utilises an idea of economically sustainable use of biomass, is also to be noted (Heräjärvi and Marttila 2016).

To date, there is no unified and internationally agreed definition of what cleantech is. For instance, Koch, Sørensen, and Wildner (2012) suggest that cleantech comprises activities which advance, manufacture, or enforce new or upgraded processes or products related to renewable energy and materials, better resources, and energy efficiency through the reduction of the use of natural resources and in overall reduced pollution. Meanwhile, various sources refer to the practical definition provided by the Cleantech Group, under which the term is represented as a wide spectrum of 'new technologies and related business models that offer competitive returns for investors and customers while providing solutions to global challenges' (Doganova and Karnøe 2015, 22). The definition has 
persisted over time, and its limited focus on sectoral social construction (Caprotti 2012), market economics and the related financial side (Guziana 2011) clearly calls for a more comprehensive interpretation.

Several sources define cleantech as an independent sector and investment category comprising the range of innovative products, services and processes designed to achieve long-term commercially- and environmentally- sustainable industrial development through the optimised use of finite and renewable natural resources (i.e. Cumming, Henriques, and Sadorsky 2016; Davies 2013; Gray and Caprotti 2011; Hermelin and Rämö 2017; Vauterin and Virkki-Hatakka 2016). There is also a pattern of attempts towards delineating cleantech firms, which are depicted as technology-oriented actors that produce, facilitate, and commercialise cleantech products, services and processes (Bjornali and Ellingsen 2014; Cumming, Henriques, and Sadorsky 2016). Firms within all industries can be part of the cleantech sector, though the major share represents actors from renewable energy and green construction (Hansen 2014). There are also several alternative attempts to classify industries. Cumming, Henriques, and Sadorsky (2016) and Cumming, Leboeuf, and Schwienbacher (2017) indicate four dominant industries: energy, transportation, water and materials and, subsequently, present a range of different energy efficient technologies, such as renewable energy technologies, recycling, and green chemistry, while Hansen (2015) lists renewable energy, smart grid, green construction, transportation and waste and water as five prevailing industries within the cleantech industry. Binz, Tang, and Huenteler (2017), by focusing on similar categories, highlight their fast development and from a spatial shift' perspective focus on specific patterns of advantages to the first movers in manufacturing and knowledge creation. More detailed categorization covers renewable energy, carbon capture and storage, green IT, sustainable construction, and smart and electric transportation (Gray and Caprotti 2011). Such industries are frequently part of the services offered by governments or are in the interest of national and local policies.

\section{GOVERNMENTAL USE OF INNOVATIVE POLICY TOOLS}

One of the main distinctions of cleantech in comparison with the traditional sectors is the high level of governmental support (Basse-Mama et al. 2013; Binz and Anadon 2018). Thus, the following sub-section presents and analyses methods of public actors' involvement in the cleantech development, based on the taxonomy of governmental innovative instru- 
ments (Aschhoff and Sofka 2009) - direct technology-push (R\&D subsidies and research units) and indirect demand-pull (regulations and public procurement).

In the following part, the outline of how contemporary cleantech fits into the model of governmental innovative policy tools and subsequently the link to public procurement is also presented.

\section{Technology-Push}

The rationale behind technology-push policies is the incremental growth of new technologies supplied to the market by investments. In the notion of mandatory governmental participation as a prerequisite of cleantech sector creation, public subsidies have become a major driving force (Basse-Mama et al. 2013). Whereas estimates vary significantly (Davies 2013), Basse-Mama et al. (2013) reveal approximate numbers of $\$ 46$ billion as the worldwide subsidies for renewable energies in 2009 and consequently $\$ 194$ billion as the clean energy stimulus funding, which together spurred interest in other private forms of investments, with an example by Davies (2013) illustrating growth by $220 \%$ between 2008 and 2010 up to $\$ 243$ billion. By means of relative numbers, Heräjärvi and Marttila (2016) represent the higher prominence of cleantech on a long-term basis, with the Finnish government spending $40 \%$ of all public research, development, and innovation funding to assist the cleantech sector. In the meanwhile, universities have begun recognising the value they can bring to bolstering cleantech, specifically in the early stages of the innovation process. However, at the current stage, universities tend to step in as traditional technology transfer actors (Kivimaa, Boon, and Antikainen 2017).

\section{Demand-Pull}

Cleantech technologies are still immature in nature and, hence, demand considerable long-term supportive policy frameworks to compete with traditional technologies based on a free market (Gray and Caprotti 2011; Yang, Nie, and Huang 2020). Such a proposition is also supported by the claims that cleantech is a public good (Cumming, Henriques, and Sadorsky 2016; Giudici, Guerini, and Rossi-Lamastra 2019) and society is the main beneficiary of the activities of cleantech firms. Companies which invest in innovative business models and develop new technologies are, therefore, particularly dependent on governmental assistance (Bjornali, Giones, and Billstrom 2017). 
While these aspects illustrate the incentive for supportive public policies, there are also restrictive policies aimed at stimulating companies to reduce their environmental footprint. For instance, Laurens et al. (2016) argue that negative environmental effects caused by larger enterprises tended to be enormously high. Thus, under national policies, there are larger investments in cleantech and overall attempts to incorporate it into organizational strategies.

Although the technology-push approach seems effective, lack of demand on the market results in the so-called 'valley of death', wherein technologies stuck in the middle phase between innovation and market commercialisation stages (Gaddy et al. 2017). Similar concerns are shared by Bürer and Wüstenhagen (2009), stating that the technology valley of death can become a serious obstacle to cleantech, and governments need to pay higher attention not only to pushing technologies, but also to fostering demand. Better cooperation with local authorities and identification of public procurement as a prospective market creator for cleantech should be one of the key points in the agendas of universities focused on cleantech (Kivimaa, Boon, and Antikainen 2017). At the same time, from the industry perspective, empirical evidence suggests that governmental contracts as the first orders allow companies not only to secure financing, but also to complete the full process of supply with a product's better tests and representations leading to opportunities for future orders (Koch, Sørensen, and Wildner 2012).

\section{CLEANTECH KNOWLEDGE CREATION \\ Cleantech SMES and Start-Ups}

SMES technologically outperforming their larger rivals has been frequently mentioned among cleantech papers. Evidence indicates varying performance among large companies, whereby us and European large firms are related to approximately $1 / 4$ and $1 / 3$ of all cleantech patents, in comparison to all Japanese cleantech patents being produced by large companies solely within the scope of the transport energy sector (Laurens et al. 2016). In contrast, indications of SMES as the driving force are present. The environmental technology sector is distinguished by the preponderance of SMES (Guziana 2011). Concepts of SMES and startups tend to be used interchangeably in the context of cleantech, with the start-ups argued to be mitigating the impact on the environment and leveraging new technologies towards environmentally friendly products and services (Giudici, Guerini, and Rossi-Lamastra 2019). Whereas 
some papers focus on smaller companies (Hansen 2014; Koch, Sørensen, and Wildner 2012; Vauterin and Virkki-Hatakka 2016), other evidence stems from the practice. That is, small start-ups are typically more inclined to deliver disruptive innovations (Basse-Mama et al. 2013) and constitute major shares of markets and sectors, with examples of Finnish SMES from the wood sector (Heräjärvi and Marttila 2016) and the Irish cleantech sector, with a small number of large enterprises (Davies 2013). At the same time, the flexibility of sMEs in comparison with the larger companies is considered another advantage, allowing them to enter new markets, such as low-carbon cities (Kapsalyamova et al. 2014).

\section{Networking and Public Involvement}

Governance of their affairs takes an important role for sMEs and startups; as companies unable to prosper in isolation, they need to collaborate and create networks. State actors, while remaining substantial participants, are not the only actors in such networks, with the main stakeholders involving public, private, and civil actors (Davies 2013). Considering the complexity of the cleantech sector, value chains are more unsettled and the key inputs to the innovation process can be dispersed among unobstructed networks (Binz and Anadon 2018). Traditional dyadic industry-government relationships affected by the hybridisation of private and public actors have resulted in the 'triple-helix model', where triadic university-industry-government allocation of power creates an emerging type of intermediary (Hermelin and Rämö 2017) which can further be supported by governments in the form of public-private partnerships (P P P S) (Cumming, Henriques, and Sadorsky 2016).

The impact of collaboration and networking in cleantech knowledge creation is stressed by scholars (Vauterin and Virkki-Hatakka 2016). Heräjärvi and Marttila (2016) pinpoint goals of clusters aimed at support of SMES, Davies (2013) discusses cleantech clusters as heterogeneous entities with the concurrence of power within economic and political sides as the core driver and consequent meta-clustering on a transnational level, and Gray and Caprotti (2011) argue over various governance systems and tiers and types of innovations. Geographical proximity is also important for better networking and partnering with large companies, where small cleantech companies take the lead in the process (Hansen 2014). Apart from clusters, close physical location is likewise reflected by urban sustainability and small closed-loop systems with the examples of zero-emission cities in the desert (Bullis 2009), eco-districts (Weber and 
Reardon 2015), transitions towards sustainability in regional development (Gibbs and O'Neill 2017) and alignment of different actors to common decentralised cleantech projects and initiatives under city ecosystem orientation (Horwitch and Mulloth 2010).

\section{Discussion}

This chapter presents dominant findings from selected papers and discusses them systematically in accordance with the research objectives. The categorisation is made based on the research design, and it encompasses both academic and practice points of view.

\section{CLEANTECH ACADEMIC RELEVANCE AND DEFINITION}

It can clearly be seen that the specificity of academic cleantech appearance outlines various avenues for future research. The latter can be achieved by appropriate synthesising of the key results with the public procurement research frameworks and, thus, areas can be mutually beneficial by narrowing one another's gaps. Alongside the relevance of public procurement and fragmented pieces of evidence supporting the claim, cleantech can be interlinked with both research streams of public procurement and industries, in which public orders are particularly prominent. Referring back to Cheng et al. (2018), cleantech can indeed be identified as a tool of framing academic investigations on environmental sustainability in public procurement. Moreover, based on a review of previous research, the following cleantech definition is proposed: Cleantech is a sector encompassing products, services and processes striving to deliver and diffuse sustainability-oriented innovations with the focus on the holistic regenerative design of processes across various industries.

More specifically, emphasis is put on the evolving importance of sophisticated design of products and services. Cleantech products and services represent key parts of networks and local clusters, whereby enhanced performance can be achieved by two key actions. Processes in such networks should supplement each other, and services should align the performance of various products within such networks. Given the variety of industries taking place, the role of such services is even more vital.

PUBLIC DEMAND AND COMMERCIALISING INNOVATIONS

Apparent indications imply the relevance of PPI as a tool for overcoming the technological valley of death, wherein technologies stuck in the 
middle phase of innovation stage and face lack of demand in attempts to commercialising. Whereas governments 'push' the technologies, mainly by financial investments, a gap between emerging cleantech innovation and successfully commercialised cleantech innovation remains (Vauterin and Virkki-Hatakka 2016). Given the overall level of governmental involvement in the cleantech sector, stimulating the demand, and thereby assisting in commercialising and diffusing of cleantech innovations, is a logical continuation of ongoing state supportive incentives. Moreover, it is a way of delivering societal benefits in the light of remarks on cleantech being a 'public good.'

\section{ENHANCING ACCESS OF SMES TO PUBLIC CONTRACTS}

Beyond delivering societal benefits, cleantech also unveils opportunities to achieve sustainability benefits through local public procurement. Cleantech companies tend to work in clusters in close geographical proximity; thus, procurement from locally located companies can ensure that taxpayers as stakeholders can be satisfied, since the public funds are invested locally.

Apart from geographical aspects, there is an issue of smEs as suppliers for public contracts. Although there is no unified taxonomy categorising the main barriers and challenges SMES face in attempting to compete for public contracts, the specificity of the cleantech context allows testing of cleantech clusters and triple-helix models. Such entities are found to be the dominant forms of networks as intermediaries between small suppliers and public customers, aligning efforts and synchronising resources and capabilities. To the extent of the inability of small single companies to overcome obstacles at each stage of the procurement process, involving intermediaries can be helpful within earlier stages of procurement. Coordinating resources and capabilities supplemented by technical, legal and language skills commonly lacked by SMEs (Jurčík 2013; Loader 2015) may become the key element in overwhelming impediments such as bureaucracy, entry mode requirements and large contract volumes. Such challenges especially relevant to the pre-tendering stage have been acknowledged by SMES as the most troublesome (Jurčík 2013). Hence, public procurement of cleantech products involving intermediaries can boost performance of sMEs and foster macro-economic objectives. Findings also suggest that public-private partnerships should attain higher recognition in the context of cleantech networks. PPPS appear to be an attractive mechanism for bolstering assets and efforts towards synchronis- 
ing expertise and technological advances, specifically through the myriad of administrative issues. At this point, proper application of the phenomenon through the lens of public procurement research can ensure higher explanatory power and lead towards the wider applicability of the results.

\section{INDUSTRIES AND SCOPES}

While public procurement is an important tool for energy efficiency and infrastructure projects (OECD n.d.), future academic studies should shed light on the mutual dependence of cleantech products and services since findings advocate that cleantech is rather a paradigm than yet another sustainability-related term. For instance, smart transportation is not tantamount to electric vehicles per se. Instead, the concepts represent a sophisticated nature whereby environmental aspects also ought to be included in design and use of vehicles, infrastructure, and logistics services. That is, procuring organisations should broaden the focus to services optimising the efficiency of products rather than these products solely. Scant cleantech empirical evidence reveals importance of pairing renewable energy production and smart transportation based on this energy, which can further be elaborated within public procurement research. At the same time, sectoral interlinkages, coupled with geographical proximity, outline spacious directions for urban sustainability and eco-districts research. For instance, zero-emission buildings, green IT, smart transportation, and other cleaner technologies in the context of urban development towards better delivery of enhanced values to society should further be investigated.

\section{Conclusion}

There is no unified and internationally agreed definition of cleantech. However, there is common agreement that it is an independent sector and investment category, which includes organisations focused on delivering innovative products, services, and processes. The focus is on sustainability, with the stress on environmental impact.

Thus, in the paper following definition was proposed: Cleantech is a sector encompassing products, services and processes striving to deliver and diffuse sustainability-oriented innovations with the focus on the holistic regenerative design of processes across various industries.

Unlike other sectors, cleantech has a high level of governmental support. This is because cleantech is considered as one of the governmental 
innovative policy tools. Both pull- and push approaches to innovation were identified. However, cleantech innovations are also meeting problems; the key issue is the valley of death, as cleantech is unable to move from innovation to the commercialisation stage. To change such a situation, a higher level of cooperation between government and other actors is required. This should be relatively easy since most of the cleantech companies are grouped into local clusters, thus there is opportunity for local procurement and cooperation. Increased cooperation will stimulate demand, and assist in commercialising and diffusing cleantech innovations. A large part of cleantech actors are sMEs, thus inclusion of sMES in public contracts will also allow improvement in cleantech commercialisation. However, SMES do not frequently participate in public contracts. Therefore, focus on sMEs' participation may, in turn, improve commercial success among cleantech products and services, after procurement by and diffusion to the public sector.

As cleantech is a relatively new concept in academia, there are opportunities for future research on public procurement within the context of cleantech. Such research should answer the following research questions:

- How can public demand for innovations stimulate commercialisation of cleantech products and services and consequent market diffusion?

- What are the implications of public procurement of cleantech products and services for local development?

- How can cleantech clusters and public-private partnerships as intermediaries improve the access of SMEs to public contracts?

- How can public procurement of cleantech products and services advance development of smart cities and eco-districts?

Future research could apply both qualitative approaches, analysing not only single organisations, but also local and industrial clusters. Comparative case studies could look at different national and regional policies and their impact on cleantech commercialisation, while quantitative work might reveal similarities and differences across locations, organisations, and sectors.

\section{Acknowledgments}

This research has been conducted with the financial support from Liikesivistysrahasto (The Foundation for Economic Education), a Finnish nonprofit funding agency. 


\section{References}

Alhola, K., and A. Nissinen. 2018. 'Integrating Cleantech into Innovative Public Procurement Process-Evidence and Success Factors.' Journal of Public Procurement 18 (4): 336-54.

Aschhoff, B., and W. Sofka. 2009. 'Innovation on Demand - Can Public Procurement Drive Market Success of Innovations?'. Research Policy 38 (8): $1235-47$.

Ashby, A., M. Leat, and M. Hudson-Smith. 2012. 'Making Connections: A Review of Supply Chain Management and Sustainability Literature.' Supply Chain Management 17 (5): 497-516.

Baker, M. J. 2000. 'Writing a Literature Review.' Marketing Review 1 (2): 219-47.

Basse-Mama, H., N. Koch, A. Bassen, and T. Bank. 2013. 'Valuation Effects of Corporate Strategic Transactions in the Cleantech Industry.' Journal of Business Economics 83 (6): 605-30.

Binz, C., and L. D. Anadon. 2018. 'Unrelated Diversification in Latecomer Contexts - The Emergence of the Chinese Solar Photovoltaics Industry.' Environmental Innovation and Societal Transitions 28:14-34.

Binz, C., T. Tang, and J. Huenteler. 2017. 'Spatial Lifecycles of Cleantech Industries - The Global Development History of Solar Photovoltaics.' Energy Policy 101:386-402.

Bjornali, E. S., and A. Ellingsen. 2014. 'Factors Affecting the Development of Clean-Tech Start-Ups: A Literature Review' Energy Procedia 58:4350.

Bjornali, E. S., F. Giones, and A. Billstrom. 2017. 'Reveal or Conceal? Signaling Strategies for Building Legitimacy in Cleantech Firms.' Sustainability 9 (10): 1815-33.

Bullis, K. 2009. 'A Zero-Emissions City in the Desert.' Technology Review 112 (2): 56-63.

Bürer, M. J., and R. Wüstenhagen. 2009. 'Which Renewable Energy Policy is a Venture Capitalist's Best Friend? Empirical Evidence from a Survey of International Cleantech Investors.' Energy Policy 37 (12): 4997-5006.

Caprotti, F. 2012. 'The Cultural Economy of Cleantech: Environmental Discourse and the Emergence of a New Technology Sector.' Transactions of the Institute of British Geographers 37 (3): 370-85.

Cheng, W., A. Appolloni, A. D’Amato, and Q. Zhu. 2018. 'Green Public Procurement: Missing Concepts and Future Trends; A Critical Review.' Journal of Cleaner Production 176:770-84.

Chicot, J., and M. Matt. 2018. 'Public Procurement of Innovation: A Review of Rationales, Designs, and Contributions to Grand Challenges.' Science and Public Policy 45 (4): 480-92. 
Correia, F., M. Howard, B. Hawkins, A. Pye, and R. Lamming. 2013. 'Low Carbon Procurement: An Emerging Agenda.' Journal of Purchasing and Supply Management 19 (1): 58-64.

Cumming, D., I. Henriques, and P. Sadorsky. 2016. 'Cleantech Venture Capital Around the World.' International Review of Financial Analysis 44 (C): 86-97.

Cumming, D. J., G. Leboeuf, and A. Schwienbacher. 2017. 'Crowdfunding Cleantech.' Energy Economics 65:292-303.

Davies, A. R. 2013. 'Cleantech Clusters: Transformational Assemblages for a Just Green Economy or Just Business as Usual?' Global Environmental Change 23 (5): 1285-95.

De Giacomo, M. R., F. Testa, F. Iraldo, and M. Formentini. 2018. 'Does Green Public Procurement lead to Life Cycle Costing Lc C Adoption?' Journal of Purchasing and Supply Management 25 (3): 100500.

Denyer, D., and D. Tranfield. 2009. 'Producing a Systematic Review.' In The SAGE Handbook of Organizational Research Methods, edited by D. Buchanan and A. Bryman, 671-89. SAGE: London.

Doganova, L., and P. Karnøe. 2015. 'Building Markets for Clean Technologies: Controversies, Environmental Concerns and Economic Worth.' Industrial Marketing Management 44:22-31.

Edler, J., and L. Georghiou. 2007. 'Public Procurement and Innovation: Resurrecting the Demand Side.' Research Policy 36 (7): 949-63.

Eßig, M., and A. H. Glas. 2016. 'Considering Small and Medium-Sized Suppliers in Public Procurement: The Case of the German Defence Sector.' In Logistics Management: Lecture Notes in Logistics, edited by D. Mattfeld, T. Spengler, J. Brinkmann and M. Grunewald, 19-33. Cham: Springer.

Flynn, A. 2017. 'Re-Thinking sme Disadvantage in Public Procurement.' Journal of Small Business and Enterprise Development 24 (4): 991-1008.

Frietsch, R., P. Neuhäusler, and O. Rothengatter. 2013. 'sme Patenting: An Empirical Analysis in Nine Countries.' Fraunhofer Is I Discussion Papers Innovation Systems and Policy Analysis 36, Fraunhofer Is I, Karlsruhe.

Frig, M., M. Fougère, V. Liljander, and P. Polsa. 2018. 'Business Infomediary Representations of Corporate Responsibility' Journal of Business Ethics 151 (2): 337-51.

Gaddy, B. E., V. Sivaram, T. B. Jones, and L. Wayman. 2017. 'Venture Capital and Cleantech: The Wrong Model for Energy Innovation.' Energy Policy 102:385-95.

Gee, S., and E. Uyarra. 2013. 'A Role for Public Procurement in System Innovation: The Transformation of the Greater Manchester U K Waste System.' Technology Analysis \& Strategic Management 25 (10): 1175-88. 
Georghiou, L., J. Edler, E. Uyarra, and J. Yeow. 2014. 'Policy Instruments for Public Procurement of Innovation: Choice, Design and Assessment.' Technological Forecasting and Social Change 86:1-12.

Gibbs, D., and K. O’Neill. 2017. 'Future Green Economies and Regional Development: A Research Agenda'. Regional Studies 51 (1): 161-73.

Giudici, G., M. Guerini, and C. Rossi-Lamastra. 2019. 'The Creation of Cleantech Startups at the Local Level: The Role of Knowledge Availability and Environmental Awareness.' Small Business Economics 52 (4): 815-30.

Gray, M., and F. Caprotti. 2011. 'Cleantech Clusters and the Promotion of the Low Carbon Transition: Criteria for Success and Evidence from Copenhagen, Masdar and Online Platforms.' Carbon Management 2 (5): 529-38.

Guerzoni, M., and E. Raiteri. 2012. 'Innovative Public Procurement and R \& D Subsidies: Hidden Treatment and New Empirical Evidence on the Technology Policy Mix in a Quasi-Experimental Setting.' Working Paper 18, Università di Torino, Dipartimento di Economia S. Cognetti de Martiis, Torino.

Guziana, B. 2011. 'Is the Swedish Environmental Technology Sector “Green”? Journal of Cleaner Production 19 (8): 827-35.

Hansen, T. 2014. 'Juggling with Proximity and Distance: Collaborative Innovation Projects in the Danish Cleantech Industry.' Economic Geography 90 (4): 375-402.

- 2015. 'Substitution or Overlap? The Relations between Geographical and Non-Spatial Proximity Dimensions in Collaborative Innovation Projects.' Regional Studies 49 (10): 1672-84.

Harwood, T. G., and T. Garry. 2003. 'An Overview of Content Analysis.' The Marketing Review 3 (4): 479-98.

Heräjärvi, H., and J. Marttila. 2016. 'The Importance of Cleantech Business for the Development of Future Wood Products Industries.' Drewno Wood 59 (197): 165-78.

Hermelin, B., and H. Rämö. 2017. 'Intermediary Activities and Agendas of Regional Cleantech Networks in Sweden.' Environment and Planning C: Politics and Space 35 (1): 130-46.

Hommen, L., and M. Rolfstam. 2009. 'Public Procurement and Innovation: Towards a Taxonomy.' Journal of Public Procurement 9 (1): 17-56.

Horwitch, M., and B. Mulloth. 2010. 'The Interlinking of Entrepreneurs, Grassroots Movements, Public Policy and Hubs of Innovation: The Rise of Cleantech in New York City.' The Journal of High Technology Management Research 21 (1): 23-30.

Jurčík, R. 2013. 'Small and Medium Size Enterprises sme and Public Procurement.' In Recent Researches in Applied Economics \& Management: 
Business Adminstration and Financial Management, edited by P. Lorca and C. Popescu, 335-9. Business and Economics Series 9. Athens: WSEAS.

Kapsalyamova, Z., T. Mezher, N. Al Hosany, and I.-T. Tsai. 2014. 'Are Low Carbon Cities Attractive to Cleantech Firms? Empirical Evidence from a Survey'. Sustainable Cities and Society 13:125-38.

Karjalainen, K., and K. Kemppainen. 2008. 'The Involvement of Smalland Medium-Sized Enterprises in Public Procurement: Impact of Resource Perceptions, Electronic Systems and Enterprise Size.' Journal of Purchasing and Supply Management 14 (4): 230-40.

Kivimaa, P., W. Boon, and R. Antikainen. 2017. 'Commercialising University Inventions for Sustainability: A Case Study of Non-Intermediating "Cleantech" at Aalto University.' Science and Public Policy 44 (5): 63144 .

Kivistö, T., and V. M. Virolainen. 2017. 'Analyzing Local and sme Participation in Public Procurement - Evidence from Seven Finnish Municipalities.' In Global Public Procurement Theories and Practices, edited by K. V. Thai, 83-97. Cham: Springer.

Knuth, S. 2018. "Breakthroughs" for a Green Economy? Financialization and Clean Energy Transition.' Energy Research \& Social Science 41:2209.

Koch, C., B. F. Sørensen, and M. Wildner. 2012. 'Cleantech Niche Development: A Small Business Perspective on Climate Change.' International Journal of Global Warming 4 (3-4): 365-82.

Laurens, P., C. Le Bas, A. Schoen, and S. Lhuillery. 2016. 'Technological Contribution of MNEs to the Growth of Energy-Greentech Sector in the Early Post-Kyoto Period.' Environmental Economics and Policy Studies 18 (2): 169-91.

Loader, K. 2015. 's mE Suppliers and the Challenge of Public Procurement: Evidence Revealed by a u K Government Online Feedback Facility.' Journal of Purchasing and Supply Management 21 (2): 103-12.

Loader, K., and S. Norton. 2015. 's me Access to Public Procurement: An Analysis of the Experiences of smes Supplying the Publicly Funded u K Heritage Sector.' Journal of Purchasing and Supply Management 21 (4): 241-50.

McCrudden, C. 2004. 'Using Public Procurement to Achieve Social Outcomes.' Natural Resources Forum 28 (4): 257-67.

Meehan, J, M. N. Ludbrook, and C. J. Mason. 2016. 'Collaborative Public Procurement: Institutional Explanations of Legitimised Resistance.' Journal of Purchasing and Supply Management 22 (3): 160-70.

Ministry of the Environment. 2013. 'Finnish Initiatives on Sustainable Consumption and Production.' Getting More from Less: Finnish Initiatives 
on Sustainable Consumption and Production. https://www.ym.fi/ download/noname/\%7B11E6CBCF-402F-4338-848A -A6F7676DoADD\%7D/58318

Myoken, Y. 2010. 'Demand-Orientated Policy on Leading-Edge Industry and Technology: Public Procurement for Innovation.' International Journal of Technology Management 49 (1-3): 196-219.

Obwegeser, N., and S. D. Müller. 2018. 'Innovation and Public Procurement: Terminology, Concepts, and Applications.' Technovation 7475:1-17.

oECD. N. d.. 'Infrastructure \& Energy in Public Procurement.' http://www .oecd.org/gov/public-procurement/infrastructure-energy/

Prier, E., and C. P. McCue. 2009. 'The Implications of a Muddled Definition of Public Procurement.' Journal of Public Procurement 9 (3-4): 326-70.

Prime Minister's Office. 2015. Finland, a Land of Solutions: Strategic Programme of Prime Minister Juha Sipiläs Government. Government Publications 12. Helsinki: Prime Minister's Office.

Rousseau, D. M., J. Manning, and D. Denyer. 2008. 'Evidence in Management and Organizational Science: Assembling the Field's Full Weight of Scientific Knowledge through Syntheses.' Academy of Management Annals 2 (1): 475-515.

Saastamoinen, J., H. Reijonen, and T. Tammi. 2018. 'Should smes Pursue Public Procurement to Improve Innovative Performance?' Technovation 69:2-14.

Seuring, S., and S. Gold. 2012. 'Conducting Content-Analysis Based Literature Reviews in Supply Chain Management.' Supply Chain Management: An International Journal 17 (5): 544-55.

Seuring, S., and M. Müller. 2008. 'From a Literature Review to a Conceptual Framework for Sustainable Supply Chain Management.' Journal of Cleaner Production 16 (15): 1699-710.

Snider, K. F., and R. G. Rendon. 2008. 'Public Procurement Policy' Journal of Public Procurement 8 (3): 310-33.

Telgen, J., C. Harland, and L. Knight. 2007. 'Public Procurement in Perspective.' In Public Procurement: International Cases and Commentary, edited by L. Knight, C. Harland, J. Telgen, K. V. Thai, G. Callender, and K. McKen, 16-24. London: Routledge.

Testa, F., E. Annunziata, F. Iraldo, and M. Frey. 2016. 'Drawbacks and Opportunities of Green Public Procurement: An Effective Tool for Sustainable Production. Journal of Cleaner Production 112 (3): 1893-900.

Thai, K. V. 2001. 'Public Procurement Re-Examined.' Journal of Public Procurement 1 (1): 9-50.

Uyarra, E., and K. Flanagan. 2010. 'Understanding the Innovation Impacts of Public Procurement.' European Planning Studies 18 (1): 123-43. 
Uyarra, E., K. Flanagan, E. Magro, and J. M. Zabala-Iturriagagoitia. 2017. 'Anchoring the Innovation Impacts of Public Procurement to Place: The Role of Conversations.' Environment and Planning C: Politics and Space 35 (5): 828-48.

Vauterin, J. J., and T. Virkki-Hatakka. 2016. 'A Typology of Knowledge Collaboration: A Case Study of an Initiative to Accelerate the Internationalization of Finnish Cleantech Entrepreneurship. Industry and Higher Education 30 (4): 292-301.

Weber, R., and M. Reardon. 2015. 'Do Eco-Districts Support the Regional Growth of Cleantech Firms? Notes from Stockholm.' Cities 49:113-20.

Wexler, S. R., R. A. Murr, and B. C. Weber. 2008. 'Convergence of Cleantech and Nanotech and the Benefits to the Nanotech Sector.' Nanotechology Law and Business 5 (3): 335-40.

Yang, Y. C., P. Y. Nie, and J. B. Huang. 2020. 'The Optimal Strategies for Clean Technology to Advance Green Transition.' Science of the Total Environment 716:134439. https://www.doi.org/10.1016/j.scitotenv.2019 .134439 . 